\title{
小型家電リサイクル法の市町村現場での施行状況と 制度見直しの課題
}

趙 迪*

\author{
Law Enforcement Status of the Act on Promotion of Recycling of Small Waste \\ Electrical and Electronic Equipment in Municipalities \\ and Future Challenges for Institutional Reform
}

Di ZHAO*

\begin{abstract}
摘 要
2012 年 8 月に制定された使用済小型電子機器等の再資源化の促進に関する法律 (以下「小型家電リサ イクル法」と略記）は, 循環型社会形成推進基本法（2000 年）の原則として位置付けた EPR (Extended Producer Responsibility, 拡大生産者責任）は組み込まずに, 使用済小型家電からの貴金属・希少金属 等の回収益を活用した自発的な取組に委ねる市場原理的制度（いわゆる,「促進型の制度」）としてス タートさせた。しかし，現状では，国が設定した回収目標に対して，2018 年度の実際の回収量はその 7 割程度に止まっているほか, 逆有償で認定事業者に引き渡している市町村は, 2017 年度の $11.0 \%$ から 2018 年度の $14.6 \%$ に増加してきた。各主体の自発的な取組に委ねた同制度が, 当初法制定時に想定して いた「採算性」を持って運用できているのか, 市町村の実施現場の実態や動向に注目した調査研究が必 要であると考えられる。

そこで本研究は, 人口が多く回収量全体に影響を及ぼすと考えられる国内政令指定都市 20 市の取組 状況を調べ, 小型家電の年間 1 人当たり回収量をもとに政令市 20 市の取組状況をグループ化し，各グ ループの代表例として岡山市, 京都市, 大阪市を選び, より詳細な調査を行った。3市の取組実態は大 きく異なり, 小型家電の回収量確保と高品位品の回収量確保の両立の難しさや, 逆有償額が一般廃棄物 処理費を上回る事案が発生していることなど, 小型家電の量的および質的回収状況や回収による採算性 等の側面から課題を明らかにした。最後に, 市町村の実施現場で発生している課題の背景にある諸要因 と小型家電に関連する事業者の属性を考慮し, 現行の対象品目を(1)携帯電話とパソコン, (2)隽帯電話や パソコン以外の高品位小型家電製品, (3)大型の家電製品, (4)雑小型家電製品, というカテゴリーに分け, さらに, 製品に含まれる金属や有害物質の含有率表示等の情報開示を義務付け，それぞれのカテゴリー に対応する「生産者」責任を明確にしていく必要があることを示した。
\end{abstract}

\section{Abstract}

In August 2012, Act on Promotion of Recycling of Small Waste Electrical and Electronic Equipment (APRSEEE) was enacted in Japan. Under the law, which is entrusted to the voluntary efforts of each entity by bypassing the basic principle of EPR (Extended Producer Responsibility) set by the Basic Act on Establishing

龍谷大学大学院政策学研究科, = 612-8577 京都市伏見区深草塚本町 67

*連絡責任者：h17d501@mail.ryukoku.ac.jp 
a Sound Material-Cycle Society (BAESMCS). The law launched a market-principle based scheme encouraging relevant parties to fulfill their responsibilities voluntarily by utilizing the revenue of precious metals, rare metals, etc. contained in waste small household appliances. However, municipalities and businesses reached only about $70 \%$ of the collection target set by the government, and the number of municipalities that hand over the collected small home appliances to certified businesses with an inverse onerous contract increased from $11.0 \%$ in 2017 to $14.6 \%$ in 2018 . Therefore, it is necessary to investigate whether the new scheme by collecting useful metals (especially rare metals) can be operated with the "profitability" that was initially envisioned at the time of enactment of the law, based on the actual conditions of implementation sites of municipalities.

This work investigated the efforts of 20 government-designated cities in Japan, which have a large population and are thought to affect the overall collection amount and grouped them into three types based on the annual collection amount of small household appliances. Then, Okayama city, Kyoto city and Osaka city were taken as the cases in point of the three groups and their current conditions regarding small home appliances recycling were analyzed as well.

The actual conditions of the three cities were found very different but their issues are rather common as summarized as: (1) difficulty in securing the collection amount of small home appliances particularly of valuable ones, (2) the cost of inverse onerous contract may exceed the normal waste disposal cost, (3) the hard-to-see expense such as personnel cost and fuel cost, (4) the asymmetry of information between municipalities and certified disposal businesses in terms of valuables in wastes such as rare metal content.

By considering the background factors of the issues that are occurring at the implementation sites of municipalities and the attributes of businesses related to small household appliances, the target recycle items were divided into: (1) mobile phones and computers, (2) high-quality small-sized products other than mobile phones and computers. (3) large household appliances, and (4) miscellaneous small household appliances. In addition, it was indicated that it is necessary to require the disclosure of information such as the indication of the content rate of metals and hazardous substances contained in products, and to clarify the "producer" responsibility for each of the above categories.

キーワード : 小型家電リサイクル法, 市場原理的制度, 拡大生産者責任, 循環型社会形成推進基本法, 責任分担

Key words : Act on Promotion of Recycling of Small Waste Electrical and Electronic Equipment, a Scheme Based on the Market Principle, Extended Producer Responsibility, Basic Law for Establishing a Sound Material-Cycle Society, Division of Responsibilities.

\section{1. はじめに}

2012 年 8 月, 「使用済小型電子機器等の再資源化 の促進に関する法律」(以下, 小型家電リサイクル 法）が制定された。個別リサイクル法の最後に制 定されたこの法律は, 他の個別リサイクル法と異な り，「小型家電は資源性を有することから，広域的 かつ効率的な回収が可能になれば, 規模の経済が 働いて, 採算性を確保しつつ再資源化することも 可能」という想定のもと ${ }^{1)}$, 生産者, 流通事業者,
消費者，市町村など各主体に責任と分担を義務付 けず，市場原理のもとで関係者の自発的な協力に より，それぞれの実情に合わせた形で再資源化を 促す「促進型の制度」2（市場原理に委ねる制度; 経 済産業省リサイクル推進課（2017）, 小林 (2014), 櫻井（2013）等の用例に従う）として制定され,そ れまでの個別リサイクル法に導入されてきた拡大 生産者責任 (Extended Producer Responsibility, 以下，EPR）を採用していないことが特徴である。 EPR の概念は, OECD の 2001 年の政府向けガ 
イダンスマニュアルによれば, 製品に対する生産者 の責任が製品消費後まで拡大する環境政策アプ ローチであると定義されている（OECD2001）。循 環型社会形成推進基本法（以下, 循環基本法) は 第 11 条で EPR の内容について, 事業者の責務と して廃棄物等となることの抑制（第 1 項）, 製品成 分の表示および製品の環境配慮設計 (第 2 項), 循 環資源の引取およびリサイクルの責務（第 3 項), リサイクル製品の利用 (第 4 項) を挙げている。本 研究で EPR が導入されていないと捉える理由は, EPR の中核的な概念である第 3 項（引取およびリ サイクル責務）に準拠している。

しかし,市場原理により促進されていくという小 型家電リサイクル法の想定は, 制度設計時の期待 通りには展開していない。2020 年 8 月，法律施行 5 年後の見直しとして, 産業構造審議会産業技術環 境分科会廃裹物・リサイクル小委員会小型家電リ サイクルワーキンググループおよび中央環境審議 会循環型社会部会小型電気電子機器リサイクル制 度および使用済製品中の有用金属の再生利用に関 する小委員会は, 2019 年 3 月から行ってきた小型 家電リサイクル制度の評価および検討を行い，「小 型家電リサイクル制度の施行状況の評価・検討に 関する報告書」(以下, 評価報告書) を提出してい る。同報告書では, 小型家電の施行状況として, 2018 年度の回収実績は 10 万トン（自治体 6.1 万卜 ン, 小売店等 3.9 万トン) で ${ }^{3)}$, 回収目標の 14 万卜 ンに達していないものの ${ }^{4)}$, 小型家電の回収·処理 を実施していると答えた自治体が，実施に向けて 調整中を含め, 2015 年度の $75 \%$ から 2018 年度の 93\%に達していることを報告している ${ }^{5) 。 た た ゙ し ， ~}$ 2017 年末から中国による使用済プラスチック等の 輸入禁止措置や金属資源価格の変動などの影響を 受け, 2013 年度から 2018 年度までの間に, 市町村 から認定事業者への逆有償による引渡し件数が 1 件から 151 件にまで増加していることも指摘し ${ }^{6)}$, 目標達成と合わせ, 重要な課題が存在しているこ とを認めている。

このような課題認識のもとに, 同報告書は, 問題 解決および緩和のための具体的な方策や今後の方 向性等として，(1)市町村および認定を受けた再資 源化事業者 ${ }^{7)}$ (以下, 認定事業者) による小型家電 回収量の拡大, (2)認定事業者の効率的なリサイク
ルの推進，(3リチウムイオン電池使用製品の排出 量の増加, 臭素系難燃剤に対する化学物質規制の 導入または強化といった新たな課題への対応の 3 点を挙げている。すなわち, (1)については, 市町村 によるステーション回収やピックアップ回収を含 む複数回収方法の実施，コス卜低減に向けた新た な技術やシステムの導入についての検討，消費者 への周知を求め, 認定事業者による直接回収の多 様化および回収拠点の拡大などを求めている。(2) については, 研究開発などの促進や業種間の連携 促進によるリサイクル技術の向上や高度化を求 め, これにより市町村からの小型家電の引渡し価 格の逆有償化傾向の緩和を図ることができると指 摘している。(3については，市町村や小売業者に よるリチウムイオン電池等の廃棄方法の消費者へ の周知, 認定事業者によるリチウムイオン電池等の 適切な解体や処理対策の採用などを求め, 生産者 にはリチウムイオン電池等の設計や表示, 分別へ の協力の他, 資源の有効な利用の促進に関する法 律（以下，資源有効利用促進法）に基づく回収体 制の構築や再資源化が必要であることに言及して いる。しかし，回収目標の未達成や逆有償ケース の増加傾向などの課題に対応するため示された同 報告書の議論は，静脈側の一層の努力を求めるの みにとどまっており，「促進型の制度」の有效性を 検証する議論は行われていない。

上記評価報告書が取り上げた小型家電回収量の 確保や回収，処理に対する採算性といった課題に ついては，法施行前からすでに市町村の採算性や 回収量の確保の可能性，環境への悪影響等が懸念 され，生産者の関与の必要性やリサイクル責任の 義務化の検討の必要性が指摘されてきた（天池 2012, 大塚 2012, 吉田 2013, 磯野 2013)。しかし ながら，小型家電製品中の資源量，特に携带電話 等に含まれる貴金属やレアメタルなどの賦存量の 推計等の研究（山末ら 2009, 相澤ら 2009）および 義務的な制度の創設による過度な義務を負うこと への業界としての懸念の表面化（杉村 2012）が「促 進型の制度」の採用を後押しし，結局同法は「促 進型の制度」として制定された。これに対して,小 林（2014）は，同法施行 5 年後に，十分なリサイ クル量・率が実現できていない場合には，EPRの 考え方を取り入れていくことを検討するべきだと 
した。前述の報告書に先立ち, 法施行後, 市町村 および認定事業者の回収処理費用の増加や金属等 の市場価格の変動, 当初想定の通りに回収が進ま ないことなどが指摘されてきた（中村 2017 , 佐藤 2017, 中野 2017)。問題解決のために, 斎藤・劉 （2016）は, 国の後押しや, 小型家電メーカーなど の製造業，小売業といった動脈産業の関与の強化 を進めていくこと，すなわち EPR 導入の検討が肝 要であると指摘している。しかし, どのような $\mathrm{EPR}$ が適切であるかなど,より立ち入った議論はまだほ とんどない。

小型家電の回収品目は多く, また回収品目の選 定は市町村の裁量に委ねられている。したがって, 他の個別リサイクル法の場合にも増して, 市町村 ごとの実態には差が表れていくはずであり，市町 村現場の実態に即した把握が必要である。市町村 現場の実状については，住民意識と回収量との関 係や回収方法の改善策などについての研究が報告 されてきた（飯野ら 2014; 岡山ら 2014; 樋口 2014; 岡本ら 2017 ; 岡本ら 2018）ほか, 斎藤・劉（2016） は, 14 の市町村と 17 の認定事業者に対する実態調 査を通じて，運搬費用の負担が同制度の採算性に 大きな影響を及ぼすこと, 複数の回収方法は回収 量の増加につながること, 市場動向の影響が課題 の一つであることなど, 国の評価報告書より早い段 階で同法の実施状況と課題を指摘した。しかし, 2017 年末から始まった「中国ショック」など，小 型家電リサイクルを取り巻く社会環境が変化し, 法施行 6 年後の市町村の実施現場ではこれまでの 研究で掲げられたものと性質の異なる問題が発生

しているはずである。

そこで, 本研究では,「促進型」として各主体の 自発的な参加に期待する小型家電リサイクル法 が, 有用金属の回収により, 市町村にとって採算性 を担保した運用ができるという法制定時の想定が 実現されているのかを，複数の市町村の現場で検 証し, 各事例を通じて市町村の実施現場が直面し ている課題を明らかにし, その上で, 改善のあり方 を検討することを目的とした。実状把握のために は, 全国の政令指定都市（以下，政令市）20市に ついて, 小型家電の回収量, 回収方法, 認定事業 者への引渡し価格等を取材し, 年間 1 人当たり回 収量をもとにグループ化し，それぞれの中から代
表的と考えられる都市について, より詳細に検討を 行うという方法を採用した。検証にあたり, (1)市町 村の採算性については認定事業者への引渡し価格 の有償または逆有償を指標として検討する。採算 性にはこの他に, 最終処分場の延命効果, 有害物 質の無害化対策費など様々な数值化しづらい 8) 要 素があるが，同法の制定によって市町村による従 来の廃棄物処理体系から使用済小型家電が区分さ れていく限り，最終処分場の延命と有害物質の無 害化処理も連動して進むものであるので, 今回の 検討項目には加えない。(2)貴金属やレアメタルな どの希少金属の回収状況 ${ }^{9)}$, および, (3)年間 1 人当 たり回収量を国が設定した回収目標 ${ }^{10)}$ と比較す るという評価軸を設定した。

\section{2. 小型家電リサイクル法の仕組みと問題}

\section{1 小型家電リサイクル法の対象品目}

小型家電等の対象品目には, 使用済小型電子機 器等の再資源化の促進に関する法律施行令 (以下, 施行令) 第 1 条で定められる「制度対象品目」と 「使用済小型電子機器等の回収に係るガイドライン (2013 年)」(以下, ガイドライン) に定められる「特 定対象品目」がある。以下に述べるように, 制度対 象品目は, 特定家庭用機器再商品化法（以下, 家 電リサイクル法) の対象となっている家電 4 品目 (エアコン, テレビ, 冷蔵・冷凍庫, 洗濯・乾燥機) 以外の全ての電子製品等であり, 特定対象品目はそ の中で資源含有率が高い電子製品等である。

制度対象品目は,「一般消費者が通常生活の用に 供する電子機器その他の電気機械器具のうち, (1 廃裹物処理法が定めた廃裹物になった場合に, 効 率的な収集運搬が可能であり，かつ(2)再資源化が 廃棄物の適正な処理および資源の有効な利用を図 る上で特に必要なもののうち, 当該再資源化に係 る経済性の面における制約が著しくないもの」(同 法第 2 条）と定義した使用済小型家電等で, 詳細 を施行令で定めるとしている。施行令第 1 条で, 制 度対象品目を 28 分類定めているが 11), マッサージ チェア，大型コピー機などの大型家電製品までが 含まれ, これらを同じ回収, 処理システムに乗せる ことになっている。

一方, 特定対象品目は, 環境省と経済産業省が 定めた「ガイドライン (2013 年)」により「資源化 
と分別のしやすさから特にリサイクルすべき品目」 として定められた 16 分類である ${ }^{12)}$ 。の 16 分類 には携带電話など貴金属やレアメタルなどの希少 金属の含有率が比較的高い高品位品が含まれてい る ${ }^{13)}$ 。

\section{2 現行の「小型家電」の回収, 処理システムの 特徵と先行研究における議論}

植田（1992）は, 生産, 流通, 消費, 廃棄の各 段階において各経済主体がそれぞれの意思のもと で行動するだけで, 動脈プロセスと静脈プロセス が分断している分断型の社会システムが廃棄物を 大量に排出する社会要因であると指摘している。 日本では 1990 年代後半以降のリサイクル関連法の 成立過程で，このような分断状態を克服するため に EPR を導入してきた。これまで, 循環基本法の 理念に基づき整備および施行された容器包装リサ イクル法 (2000 年), 家電リサイクル法 (2001 年), 建設リサイクル法 (2002 年), 自動車リサイクル法 (2005 年) にはEPR が採用された。ただし, 食品 リサイクル法（2001 年）では, 食品廃棄物と工業 製品とでは環境負荷の質的・量的な相違が認めら れ, 明確な EPR は導入されなかった（小林 2014）。 個別リサイクル法の最後に制定された小型家電リ サイクル法は, 有用金属の確保による資源の循環 的利用, 廃裹物の減量化などを目的としている ${ }^{14)}$ が, 義務化で一つの方法に限定するよりも様々な これまでのリサイクルの取組を包含する方が望ま しい 15) とし, 法律的な義務としての EPR は採り入 れなかった。

具体的には, 小型家電の回収, 処理フローに関与 している各主体の責任分担について, 同法第 9 条で は, 生産者は「小型家電等の設計およびその部品又 は原材料の種類を工夫することにより使用済小型 家電等の再資源化に要する費用を低減するととも に, 使用済小型家電等の再資源化により得られた物 を利用するよう努めなければならない」としてい る。同法第 8 条では, 流通事業者 (小売業者) は 「消費者による使用済小型家電等の適正な排出を 確保するために協力するよう努めなければならな い」とし, 同法第 6 条では, 消費者は「使用済小型 家電等を排出する場合にあっては, 当該使用済小型 家電等を分別して排出し, 市町村その他使用済小
型家電等の収集若しくは運搬又は再資源化を適正 に実施し得る者に引き渡すよう努めなければなら ない」と規定している。同法第 5 条では, 市町村は 「その区域内における使用済小型家電等を分別し て収集するために必要な措置を講ずるとともに, そ の収集した使用済小型家電等を第 10 条の規定によ る認定事業者その他使用済小型家電等の再資源化 を適正に実施し得る者に引き渡すよう努めなけれ ばならない」とし, 第 12 条では, 認定事業者に市 町村からの使用済小型家電等の引取り責務を定め, 第 13 条では, 認定事業者による広域的な収集, 運 搬, 再資源化について市町村長または都道府県知 事による許可要件の緩和などを定めている。

このように, 同法は, 生産者などに小型家電の引 取や適正処理およびリサイクルの責任または費用 負担を求めておらず, 製品の生産・流通の上流段 階から回収・処理の下流段階まで, 生産者, 流通 事業者, 消費者, 市町村, 認定事業者など各主体 の役割分担について，「努めなければならない」と 定めるに止まり,もっぱら市町村と認定事業者に小 型家電の売却益の中から回収および再資源化コス 卜を捻出させる仕組みである。すなわち, 強制力を 伴わず市場原理に任せるという小型家電リサイク ル法は, 生産者責任を希少金属という形で小型家 電製品の中に閉じ込め, 鍵のかかった「宝箱」と し，認定事業者が鍵を開けて取り出した「宝」を 市町村や収集運搬業者と分け合うというプロセス が市場原理的に成り立つという考えに立脚してい るのである。

各主体の自発的協力に委ねる「促進型の制度」と して小型家電リサイクル法が有効であるためには, 消費者の手から廃裹小型家電がスムーズにリサイ クルラインに排出され，それが市町村等の手で認 定業者に持ち込まれ, 認定業者のところで上記の 「宝」が回収され，その売却益が市町村や収集運搬 者に還流され収集運搬費用を賄う，という全体の プロセスが成り立つことが必要である。したがっ て, (1)市町村等の回収, 収集, 運搬コストを含め, 小型家電の回収, 処理は市場原理的システムの中 で「採算性」が実現できていること, (2)「宝」であ る貴金属やレアメタルをはじめとする希少金属確 保が効果的にできていること, (3)回収量が事業性 を保証する程度に達している (1)とも関係する)こ 
とである。そこで, 先行研究がこれらの点について どのような指摘を行ってきたかを見てみたい。

上記(1)については，小型家電リサイクル法の制 定に対して, 当初から市町村や認定事業者の採算 性を懸念する指摘があった。「使用済小型電子機器 等の再資源化の促進に関する基本方針（2013 年)」 （以下，基本方針）では「採算性を確保しつつ再資 源化」との展望を示していたが, 2011 年度から 2019 年度の資源価格の推移によれば，金の市場価格は 変動せずに安定しているものの，鉄，アルミ，銅な ど多くの金属の市場価格は変動を繰り返してい る ${ }^{16)}$ 。吉田（2013）は，小型家電リサイクル制度 は,リサイクル業者には回収コストと金属価格の変 動リスクが伴うとの懸念を示していた。法施行後 にも, 同制度は, 市場原理に基づく経済性をインセ ンティブとした促進法と位置付ける以上，価格変 動をいかに吸収するかが大きな問題となるとの指 摘（中野 2017）がある。また, 飯野ら（2017）は 行政の立場から「行政は回収方法を分かりやすく 整理し，広報活動を行い，適正価格で金属資源を 売却し,行政コストを削減する」ことを期待してい るが，総務省が 2017 年度に公開した報告書には, 2015 年度末に小型家電リサイクルにより損失が生 じている市町村が調查対象の $15.3 \%$ になると記載

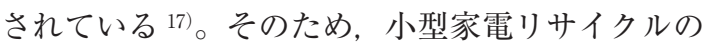
実施により, 市町村で発生している損失を解決ま たは緩和する必要があると考えられる。

(2)については, 多品目にわたる小型家電から希 少金属等の有価物を確実に回収するための情報の 欠如への指摘である。法施行前に細田（2011）は, 使用済小型家電リサイクルのためのレジーム作り を後押しする力はレアメタルの回収であると指摘 しているが，小型家電には製品中に含有するレア メタル等の希少金属の含有量情報は表示されてい ない。そのことが希少金属等の確実な回収の障害 となる。これに対して大塚 (2012) は, 小型家電の 生産者に製品へのレアメタルなどの識別表示を提 案し, 飯野ら（2017）は, 希少金属の含有とその 量に関する情報開示を生産者に求めている。この ような生産者からの情報開示が市町村の回収品目 選定時に重要な根拠を提供するものであり，希少 金属等の確実な回収に必要であるといえる。

(3)の小型家電回収量の確保については, 法施行
前に，他の電気製品と異なり製品売買だけではな く, 通信契約を伴う携带電話の回収について, 中野 （2012）は，消費者の小型家電の排出行動や意識に 関するアンケート調査を通じて，個人情報の漏洩 への懸念から消費者に携帯電話を退蔵する傾向が 見られることを指摘していた。吉田（2013）は, 法 制定前の社会実験において小型家電の回収率が 5\%程度にとどまったことを受け，回収率の低さの 理由として，「自治体にとっては，リサイクルへの インセンティブは少ない」ことを指摘していた。法 施行後に, 佐藤（2017）は，小型家電の回収目標 14 万トンに対して，2015 年度末の 6.7 万トンの回 収実績では，法律が本来目的とした状態を達成で きていないと指摘している。以上，これまで，排出 者側，市町村側ともに積極的な排出および回収イ ンセンティブが生じないという問題について議論 がなされてきた。

しかし, 先行研究においては, インセンティブが ない理由として回収量が少ないことや市町村等の 採算性が得にくいことが多く指摘されたものの, 回 収品目の質への注目が少なく, 回収量と質との関係 や，採算性が得にくい程度について十分に議論さ れたとはいえない。これまでの個別リサイクル法と 異なり，小型家電リサイクル法の着眼点は資源確 保（藤田 2013）である。したがって，家電 4 品目 から取り残されていた小型家電に含まれる希少金 属がどの程度リサイクルされるかは採算性に直結 しており, 回収量だけではなく, 回収品目の質的確 保を重視する必要がある。しかし，市町村の採算 性には評価報告書では十分明らかになっていない 多様な要因が関与しているものと考えられる。以 上により，各市町村の実状に迫った研究が必要で あるといえる。

\section{3. 市町村における小型家電リサイクル法の実 施現状}

そこで，まず，調査対象都市の選定を行った。中 央環境審議会・産業構造審議会合同会合（2020）の 市町村の取り組み状況に対する調査結果によると, 2018 年度 1 人当たり回収量は人口規模が多くなる ほど, 減少する傾向がみられるとされている。その うち，人口 3-5 万人未満の市町村では， 1 人当たり 回収量が $1191 \mathrm{~g}$ と最も多いのに対して，都市化の 
進んだ人口 100 万人以上の市町村では, 小型家電 の利用量も多いと考えられるにもかかわらず, 1 人 当たり回収量は $287 \mathrm{~g}$ で最も少ないとされている。

したがって, 人口の多い市町村が直面する課題 を明らかにすることが重要であると考える。100万 人以上の都市はすべて政令市であることから, 政 令市 20 市を調查対象に, 各市のリサイクル担当課 に電話および訪問取材をし, 小型家電リサイクル の現状の概観を行った。その後, より詳細な調査 を行うため, 政令市 20 市中から具体的な研究対象 を選び, 市町村における小型家電リサイクルの現 状の解明を試みた。

\section{1 政令 20 都市の現状の概観}

2018 年度の小型家電の回収量, 回収方法, 回収 ボックスのサイズ, 回収対象品目, 認定事業者へ の引渡し価格の有償または逆有償について, 現状 の概観を行った。中央環境審議会と産業構造審議 会が小型家電の回収傾向を分析する際に採用した 方法を参考にし，1 人当たり回収量で分けること で, 各市の取組とのつながりを考えやすく, 実施現 場で起きている問題を考えるうえでわかりやすい と考え, 年間 1 人当たり回収量で政令市 20 市をグ ループ化した。結果を回収量順で表 1 に示す。年 間 1 人当たり回収量から見ると, 国が揭げた目標 1 $\mathrm{kg}$ に近いのは 2 市だけで, 残りの市の年間 1 人当 たり回収量は $200 \mathrm{~g}$ 未満であり, この 2 市と大きな 差があることがわかった。そのため, 年間 1 人当た り回収量が突出して多いこの 2 市を第 1 グループ にし，上記の 2 市を除外した平均值を計算し，そ の平均值より多い市を第 2 グループに, その平均 值より少ない市を第 3 グループとした。ここで, ボックス回収とは, 市町村が設置した回収ボックス により回収する方式, 対面回収とは, 公共施設や商 業施設など指定回収場所に直接持ち込む方式であ る。イベント回収とは, 催事開催時に回収ボックス を設けて回収する方法であり, 清掃工場などへの 持ち込みとは, 消費者が清掃工場や資源化セン ター等に直接持参する方式である。また, ピック アップ回収とは, 不燃ごみステーションや粗大ごみ 排出指定場所から収集した不燃ごみおよび粗大ご みから小型家電を選別して回収する方式である。

表 1 に示したように, 年間 1 人当たり回収量か
ら, 国が立てた回収目標 $1 \mathrm{~kg} に$ 近い第 1 グループ, 第 1 グループ以外の年間 1 人当たり回収量の平均 $54 \mathrm{~g}$ 以上の第 2 グループ, 平均 $54 \mathrm{~g}$ 以下の第 3 グ ループに分けることができる。年間 1 人当たり回収 量がいずれも $850 \mathrm{~g}$ 以上と突出して多い静岡市, 岡 山市を第 1 グループ, 続いてこの 2 市を除いた 18 市の平均 1 人当たり回収量 $54 \mathrm{~g}$ 以上の京都市, 北 九州市, 相模原市, 札幌市, 浜松市, 名古屋市, さ いたま市, 仙台市の 8 市を第 2 グループ, $54 \mathrm{~g}$ 未 満の 10 市を第 3 グループとする。

次に, 各グループの中から 1 市を選び, より詳細 に現状を把握することとした。第 1 グループから， 回収品目の制限がないピックアップ回収方法の位 置付けを明らかにするために, 2018 年度小型家電 のピックアップ回収が回収量の大部分を占め, 有 償で引き渡している岡山市, 第 2 グループから, 年 間 1 人当たり回収量が最も多く, 取り組み方法など 多くの工夫を採り入れたが, 逆有償で引き渡して いる京都市, さらに第 3 グループから, 年間 1 人当 たり回収量が少なく, 関西経済の中心地で人口規 模以上に周辺自治体への影響が大きいと考えられ る大阪市を選び, この 3 市を通じて小型家電リサ イクル法の実施状況を検証した。

\section{2 岡山市, 京都市, 大阪市における小型家電リ サイクル法の実施状況}

\subsection{1 岡山市における小型家電リサイクル法の実} 施状況 ${ }^{18)}$

岡山市は法律制定後の 2015 年度から本格的に小 型家電リサイクルに取り組んでいる。以下に岡山 市における小型家電の回収・処理システムおよび 回収品目, 回収量, 認定事業者への引渡し価格等 の実態を述べる。

\section{（1）回収・処理システムと回収品目}

2019 年度現在, 岡山市が関与する小型家電の回 収ルートは, (1)市の区役所や資源回収場所に設置 した回収ボックスによる回収 (8 か所), 市内の協 力電気店での回収コンテナによる回収 (105 店埔), (2)イベント回収, (3)不燃ごみや粗大ごみからの

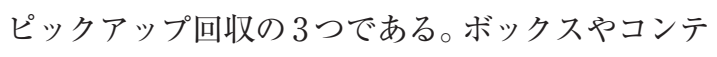
ナでの回収については, 認定事業者が巡回し, 回 収している。一方, ピックアップ回収については, 市の直営または委託業者が不然ごみステーション 
表 12018 年度政令市における小型家電リサイクルの取組状況

\begin{tabular}{|c|c|c|c|c|c|c|c|c|c|c|c|c|}
\hline \multirow{3}{*}{$\begin{array}{l}ク ゙ \\
ル \\
1 \\
フ^{\circ}\end{array}$} & \multirow{3}{*}{ 都市名 } & \multirow{3}{*}{$\begin{array}{c}\text { 人口 (人) } \\
\text { 2019年 } \\
\text { 1月 1日現在 }\end{array}$} & \multirow{3}{*}{$\begin{array}{c}2018 \text { 年度 } \\
\text { 回収量 } \\
(\mathrm{t})\end{array}$} & \multirow{3}{*}{$\begin{array}{c}\text { 一人当たり } \\
\text { 回収量 } \\
(\mathrm{g})\end{array}$} & \multicolumn{5}{|c|}{ 2018 年度回収方法 } & \multirow{3}{*}{$\begin{array}{c}\text { 回収ボックス } \\
\text { •サイズ } \\
(\mathrm{cm})\end{array}$} & \multirow{3}{*}{ 回収対象品目 } & \multirow{3}{*}{$\begin{array}{c}2018 \text { 年度 } \\
\text { 認定事業者への } \\
\text { 引渡 } \\
\text { (有償・逆有償) }\end{array}$} \\
\hline & & & & & \multicolumn{4}{|c|}{ 消費者の直接排出 } & \multirow{2}{*}{ 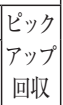 } & & & \\
\hline & & & & & \begin{tabular}{|c|} 
ボックス \\
回收 \\
\end{tabular} & $\begin{array}{l}\text { 対面 } \\
\text { 回収 } \\
\end{array}$ & \begin{tabular}{|l|} 
ベントト \\
回収 \\
\end{tabular} & $\begin{array}{c}\text { 清掃工場等 } \\
\text { 持ち込み }\end{array}$ & & & & \\
\hline \multirow{2}{*}{1} & 静岡市 & 702,395 & 599.0 & 852.8 & $\bigcirc$ & - & 0 & 0 & - & $15 \times 26$ & 制度対象品目 & 有償・逆有償 \\
\hline & 岡山市 & 709,241 & 603.9 & 851.5 & 0 & - & 0 & - & 0 & $30 \times 15$ & 制度対象品目 & 有償 \\
\hline \multirow{8}{*}{2} & 京都市 & $1,412,570$ & 274.0 & 194.0 & 0 & $\bigcirc$ & 0 & - & $\triangle$ & $30 \times 40 \times 40$ & $\begin{array}{l}\text { 回収ボックスの投入口に入 } \\
\text { る家電製品 }\end{array}$ & 逆有償 \\
\hline & 北九州市 & 955,935 & 170.0 & 177.8 & $\bigcirc$ & - & - & - & $\triangle$ & $25 \times 8.5$ & $\begin{array}{l}\text { 回収ボックスの投入口に入 } \\
\text { る家電製品。粗大ごみから } \\
\text { 独自に決めた品目 } \\
\end{array}$ & 逆有償 \\
\hline & 相模原市 & 718,367 & 116.4 & 162.0 & $\bigcirc$ & $\bigcirc$ & - & - & $\triangle$ & $30 \times 15$ & $\begin{array}{l}\text { 回収ボックスの投入口に入 } \\
\text { る家電製品 }\end{array}$ & 有償 \\
\hline & 札棍市 & $1,955,457$ & 172.7 & 88.3 & $\bigcirc$ & - & - & - & - & $30 \times 30$ & $\begin{array}{l}\text { 回収ボックスの投入口に入 } \\
\text { る家電製品 }\end{array}$ & 有償 \\
\hline & 浜松市 & 804,780 & 70.7 & 87.9 & $\bigcirc$ & - & - & - & - & $15 \times 60 \times 30$ & $\begin{array}{l}\text { 回収ボックスの投入口に入 } \\
\text { る特定対像品目 }\end{array}$ & 有償 \\
\hline & 名古屋市 & $2,294,362$ & 166.0 & 72.4 & $\bigcirc$ & - & $\bigcirc$ & - & - & $15 \times 40 \times 25$ & $\begin{array}{l}\text { 回収ボックスの投入口に入 } \\
\text { る特定対象品目 }\end{array}$ & 逆有償 \\
\hline & さいたま市 & $1,302,256$ & 92.0 & 70.7 & $\bigcirc$ & - & $\bigcirc$ & $\triangle$ & - & $30 \times 15$ & $\begin{array}{l}\text { 回収ボックスの投入口に入 } \\
\text { る家電製品と付属品、電池 } \\
\text { 及びすべての特定対象品目 }\end{array}$ & 有償 \\
\hline & 仙台市 & $1,062,585$ & 66.7 & 62.7 & $\bigcirc$ & - & O & - & $\triangle$ & $30 \times 15$ & $\begin{array}{l}\text { 回収ボックスの投入口に入 } \\
\text { る家電製品。粗大ごみから } \\
\text { 独自に決めた品目 }\end{array}$ & 有償 \\
\hline \multirow{10}{*}{3} & 福岡市 & $1,540,923$ & 50.1 & 32.5 & $\bigcirc$ & - & - & - & $\triangle$ & $25 \times 8.5$ & $\begin{array}{l}\text { 回収ボックスの投入口に入 } \\
\text { る家電製品 }\end{array}$ & 有償 \\
\hline & 新潟市 & 792,868 & 21.9 & 27.6 & 0 & O & 0 & - & - & $15 \times 35 \times 20$ & $\begin{array}{l}\text { 回収ボックスの投入口に入 } \\
\text { る家電製品 }\end{array}$ & 有償 \\
\hline & 堺市 & 837,773 & 22.2 & 26.5 & $\bigcirc$ & - & $\triangle$ & - & - & $15 \times 30$ & $\begin{array}{l}\text { 回収ボックスの投入口に入 } \\
\text { る特定対象品目 }\end{array}$ & 0円 \\
\hline & 千葉市 & 970,049 & 23.1 & 23.8 & $\bigcirc$ & - & - & - & - & $30 \times 15$ & $\begin{array}{l}\text { 回収ボックスに投入可能な } \\
\text { 下記の製品 } \\
\text { 1. 小型家電 } 21 \text { 品目 } \\
\text { 2. 携帯電話、スマホ } \\
\text { 3.ノート PC、タブレット } \\
\end{array}$ & 有償 \\
\hline & 広島市 & $1,196,138$ & 24.8 & 20.8 & $\bigcirc$ & - & $\bigcirc$ & - & - & $15 \times 30 \times 40$ & $\begin{array}{l}\text { 1. ボックス回収 : 投入口に } \\
\text { 入る家電製品 } \\
\text { 2. イベント回収 : 法律で定 } \\
\text { めた小型家電 }\end{array}$ & 逆有償 \\
\hline & 川崎市 & $1,500,460$ & 27.0 & 18.0 & $\bigcirc$ & - & $\bigcirc$ & - & $\triangle$ & $30 \times 30 \times 15$ & $\begin{array}{l}\text { 回収ボックスの投入口に入 } \\
\text { る家電製品。小物金属や粗 } \\
\text { 大ごみからの小型家電製品 } \\
\text { (サイズの大きなものを除く) }\end{array}$ & 有償 \\
\hline & 神戸市 & $1,538,025$ & 27.6 & 18.0 & $\bigcirc$ & - & $\bigcirc$ & - & - & $30 \times 40 \times 35$ & $\begin{array}{l}\text { 回収ボックスの投入口に入 } \\
\text { る家電製品 }\end{array}$ & 有償 \\
\hline & 横浜市 & $3,745,796$ & 55.7 & 14.9 & 0 & - & $\bigcirc$ & - & - & $30 \times 15$ & $\begin{array}{l}\text { 回収ボックスの投入口に入 } \\
\text { る家電製品 }\end{array}$ & 有償 \\
\hline & 大阪市 & $2,714,484$ & 21.0 & 7.7 & 0 & - & $\bigcirc$ & - & - & $15 \times 30$ & $\begin{array}{l}\text { 回収ボックスの投入口に入 } \\
\text { る家電製品 }\end{array}$ & 有償 \\
\hline & 熊本市 & 734,105 & 4.0 & 5.5 & 0 & $\bigcirc$ & - & - & - & $25 \times 10$ & $\begin{array}{l}\text { 1. 回収ボックスに投入可能 } \\
\text { な家電 } 30 \text { 品目 } \\
\text { 2. 回収カゴまたは対面で回 } \\
\text { 収する } 11 \text { 品目 }\end{array}$ & 有償 \\
\hline
\end{tabular}

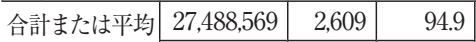

\begin{tabular}{l|r|r|r|} 
1グループを除く & $26,076,933$ & 1,406 & 53.9 \\
\hline
\end{tabular}

○完全に実施； $\triangle$ 限定的に実施；一実施なし

2019 年 7 月〜 2019 年 10 月までの各市への取材調查により作成 
表 2 岡山市における小型家電リサイクル制度への取組状況

\begin{tabular}{|l|c|c|c|c|c|}
\hline \multicolumn{1}{|c|}{ 年度 } & 2015 & 2016 & 2017 & 2018 & 2019 \\
\hline ピックアップ回収量 [t/年] & 398 & 401 & 407 & 517 & - \\
\hline ボックス回収量 [t/年] & 50 & 60.7 & 64.6 & 87 & - \\
\hline 全体回収量 [t/年] & 448 & 462 & 471 & 604 & - \\
\hline 1 人当たり 回収量 [kg/(年・人)] & 0.63 & 0.65 & 0.66 & 0.85 & - \\
\hline 希少金属の回収状況 & - & - & - & - & - \\
\hline 引渡価格 [円 $/ \mathrm{kg}]$ & 3 & 3 & 3 & 1 & 1 \\
\hline
\end{tabular}

岡山市環境事業課へのヒアリングにより作成

や粗大ごみ排出指定場所から不燃ごみおよび粗大 ごみを回収し, 東部または西部リサイクルプラザま で運搬し, 小型家電を他のものから選別し, そこで 認定事業者に引き渡している。

岡山市における小型家電の回収品目について は, 法律施行令で定めた 28 種類の制度対象品目全 てを回収対象にしている。具体的に, ボックスとコ ンテナによる回収の場合，ボックスの投入口（30 $\mathrm{cm} \times 15 \mathrm{~cm})$ とコンテナに入るものが対象品目で ある。ピックアップ回収の場合, 小型家電の大きさ の制限は設けていない。

（2）回収量, 認定事業者への引渡し価格，希少 金属の回収状況

岡山市における制度開始の 2015 年度からの小型 家電の回収量, 1 人当たり回収量, 希少金属の回収 状況および認定事業者への引渡し価格を表 2 に示 す。

表 2 から言えることは, 岡山市の場合はピック アップによる回収量が小型家電回収量の多くを占 めていること, 2019 年度まで認定事業者に有償で 小型家電を引き渡してきたことである。希少金属 の回収状況については, 岡山市は回収した小型家 電の内訳を把握していないが, 携帯電話をはじめ とした希少金属の含有が高い高品位の小型家電は 少なく，低品位のものが多いということであった 19)。低品位の小型家電からは鉄などのリサイクルが 行われるが，希少金属の回収はほとんどない20)。 2018 年度年間 1 人当たり回収量 $0.85 \mathrm{~kg}$ は, 国が揭 げた回収目標 $1 \mathrm{~kg}$ に近い。

\subsection{2 京都市における小型家電リサイクル法の実 施状況 ${ }^{21)}$}

京都市は法施行前の 2009 年度, 環境省および経
済産業省のモデル事業として法制度の施行前に, 小型家電の回収およびリサイクルを全国に先立っ て実施している。当初, 回収対象は 15 品目であっ たが，2011 年 6 月から 34 種類に増加し，2014 年 10 月から家電 4 品目, パソコン, 石油・灯油ストー ブ以外の回収ボックス $(15 \mathrm{~cm} \times 25 \mathrm{~cm})$ に投入で きる全ての家電製品を対象にしてきた。2015 年 5 月からは回収ボックスの投入口のサイズをさらに 拡大している $(30 \mathrm{~cm} \times 40 \mathrm{~cm} \times 40 \mathrm{~cm})$ 。以下に 京都市における小型家電の回収・処理システムお よび回収品目, 回収量, 認定事業者への引渡し価 格等の実態を述べる。

\section{（1）回収・処理システムと回収品目}

2019 年度現在，京都市が関与する小型家電の回 収ルートは，(1)公共施設や商業施設に設置した回 収ボックスによる回収やまち美化事務所に直接持 ち込む拠点回収 (52 か所), (2)イベント回収, (3)協 力電気店で購入する製品と同種同数の小型家電を 無料で回収する対面回収 (約 200 店舗), (4)粗大ご みからのピックアップ回収が行われておらず，缶・ びん・ペットボトル，プラスチック製容器包装など の資源ごみに混入された小型家電をピックアップ して回収する，いわゆる，資源ごみからのピック アップ回収の 4 つである。京都市が 4 つの方法に より収集した小型家電を一時保管施設まで運搬 し, 認定事業者は一時保管施設に出向き, 自社の 処理施設まで運ぶことになっている。2017 年度以 降，一時保管施設まで回収したものを認定事業者 に引き渡す前に，その中から携帯電話など希少金 属を多く含む高品位のものを市職員が選別し，他 のルートで精錬業者を通じて粗金を抽出し，京都 マラソンのメダル作成や祇園祭の山鉾の懸装品復 
表 3 京都市における小型家電リサイクル制度への取組状況

\begin{tabular}{|l|c|c|c|c|c|c|}
\hline \multicolumn{1}{|c|}{ 年度 } & 2013 & 2014 & 2015 & 2016 & 2017 & 2018 \\
\hline 回収量（全体回収量）[t/年] & 20 & 24 & 111 & 148 & 183 & 274 \\
\hline 1 人当たり回収量 [kg/ (年・人)] & 0.01 & 0.02 & 0.08 & 0.10 & 0.13 & 0.19 \\
\hline 希少金属の回収状況 & - & - & - & - & - & 金 $74 \mathrm{~g}$ \\
\hline 引渡価格 [円 $/ \mathrm{kg}]$ & -5 & 2.16 & 3.24 & -4.76 & $\begin{array}{r}(4-6 \text { 月 })-1.1 \\
(7-9 \text { 月 })-10.8 \\
(10-3 \text { 月 })-19.4\end{array}$ & $\begin{array}{r}(4-6 \text { 月 })-24.84 \\
(10-12 \text { 月 })-43.2 \\
(1-3 \text { 月 })-60.8\end{array}$ \\
\hline
\end{tabular}

京都市循環型社会推進部ごみ減量推進課へのヒアリングにより作成

表 4 大阪市における小型家電リサイクル制度への取組状況

\begin{tabular}{|l|c|c|c|c|c|}
\hline \multicolumn{1}{|c|}{ 年度 } & 2014 & 2015 & 2016 & 2017 & 2018 \\
\hline 回収量（全体回収量）[t/年 & 12 & 14 & 13 & 15 & 21 \\
\hline 1 人当たり 回収量 $[\mathrm{kg} /($ 年・人) $]$ & 0.005 & 0.005 & 0.005 & 0.006 & 0.008 \\
\hline 希少金属の回収状況 & - & - & - & - & - (鉄 $5 \mathrm{t}$, 銅 $1 \mathrm{t}$ ) \\
\hline 引渡価格 [円 $/ \mathrm{kg}]$ & 43.2 & 48.6 & 59.4 & 59.4 & 59.4 \\
\hline
\end{tabular}

大阪市環境局事業部家庭ごみ減量課へのヒアリングにより作成

元に活用している。

京都市における小型家電の回収品目について は, 上記 4 つの回収方法のいずれも, 回収ボック ス $(30 \mathrm{~cm} \times 40 \mathrm{~cm} \times 40 \mathrm{~cm})$ 以内のものを回収 対象にしている（家電 4 品目, パソコン, 石油・灯 油ストーブを除く)。

（2）回収量, 認定事業者への引渡し価格, 希少

\section{金属の回収状況}

京都市における 2013 年度からの小型家電の回収 量, 1 人当たり回収量, 希少金属の回収状況および 認定事業者への引渡し価格を表 3 に示す。

表 3 では, 2014 年度から 2015 年度にかけて回収 量が 4 倍以上に増えている。この原因は, 回収ボッ クスのサイズ拡大と, 協力電気店での無料回収の 実施が寄与したためである。2015 年度以降の回収 量の増加要因としては, 回収ボックスの増設があ げられる。2017 年度以降の回収量の増加要因とし ては, 京都マラソンのメダル作成や祇園祭の山鉾 の懸装品復元など, 回収した高品位の小型家電か ら抽出した金の活用が，市民の小型家電回収の関 心向上に寄与したことなどがあげられる。

引渡し価格については, 2013 年度は逆有償で,
2014 年度と 2015 年度は有償で, 引き渡していた。 2016 年度以降は再び逆有償になり, 2017 年度には 認定事業者と 3 回の契約改定を, 2018 年度には 4 回の契約改定を行っている。希少金属の回収につ いては, 2018 年度に認定事業者への引渡しとは別 ルートで抽出された粗金は約 $74 \mathrm{~g}$ であり, 貴金属 の回収に一定の成果をあげている。しかし, 回収 された金の持つ潜在的市場価值（2018 年度金の市 場相場で概算して約 34 万円 ${ }^{22)}$ ) を, 2018 年度小型 家電の認定事業者への逆有償での引渡し額の総額 (概算で 1 千万円 ${ }^{23)}$ ) と比べると，わずかでしかな い。2018 年度年間 1 人当たり回収量は $0.19 \mathrm{~kg}$ で国 の目標の 2 割程度であった。

\subsection{3 大阪市における小型家電リサイクル法の実 施状況 24)}

大阪市は, 法律制定後の 2014 年 3 月から小型家 電の回収を本格的に始めた。以下に大阪市における 小型家電の回収・処理システムおよび回収品目, 回 収量, 認定事業者への引渡し価格等の実態を述べ る。

（1）回収・処理システムと回収品目

2019 年度現在, 大阪市が関与する小型家電の回 
収ルートは，(1)公共施設だけに設置した回収ボッ クスによる回収 (41 か所), (2)イベント回収の $2 つ$ である。大阪市では, 回収ボックスに排出されたも のを市職員が回収し市内の環境事業センター（11 か所）に集め, 市職員が認定事業者の処理施設ま で搬送することになっている。大阪市では, 回収 ボックスの投入口 $(15 \mathrm{~cm} \times 30 \mathrm{~cm})$ に入るものを 回収対象としている。

（2）回収量, 認定事業者への引渡し価格, 希少

\section{金属の回収状況}

大阪市における制度開始の 2014 年度からの回収 量, 1 人当たり回収量, 希少金属の回収状況および 認定事業者への引渡し価格を表 4 に示す。

表 4 に示したように, 大阪市の回収量は 2018 年 度現在までわずかな増加にとどまっている。その 原因としては, 回収ボックスの設置場所が公共施 設に限られ, 市民にとって利便性の高い配置に なっていないこと, 回収ボックスの投入口が小さ く, 回収対象が限られていることが考えられる。

引渡し価格については, 小型家電リサイクル制 度に参加して以来, 認定事業者への引渡しが逆有 償になったことはない。有償での引渡しが実現で きている理由は, (1)小型家電の回収ボックスを, 蛍 光灯管や乾電池などの回収拠点に併設し, 既存の 回収体系を活用していること, (2)収集した小型家 電を市職員が直接認定事業者に運搬するため, 収 集運搬委託金が発生していないことにある。しか し，2018 年度に小型家電から回収された金属の内 訳としては鉄 $5 \mathrm{t}$, 銅 $1 \mathrm{t}$ などベースメタルが多くを 占め, 希少金属の回収量は少ないということで あった ${ }^{25)}$ 。 2018 年度の小型家電の年間 1 人当たり 回収量は $0.008 \mathrm{~kg}$ にすぎない。

\subsection{4 岡山市, 京都市, 大阪市の実施状況のまとめ}

岡山市, 京都市, 大阪市 3 市における小型家電 リサイクルの実施状況を比較し表 5 に示す。

表 5 から言えることは, 各市の回収量, 回収方 法等は大きく異なり, 認定事業者への引渡し価格 の有償または逆有償および貴金属やレアメタルな どの希少金属の回収状況, 年間 1 人当たり回収量 の目標達成度という 3 分野すべてで好実績をあげ ている市はないということである。

岡山市と京都市が逆有償になった原因は, 市況 の変動と収集運搬コストの問題による。岡山市の

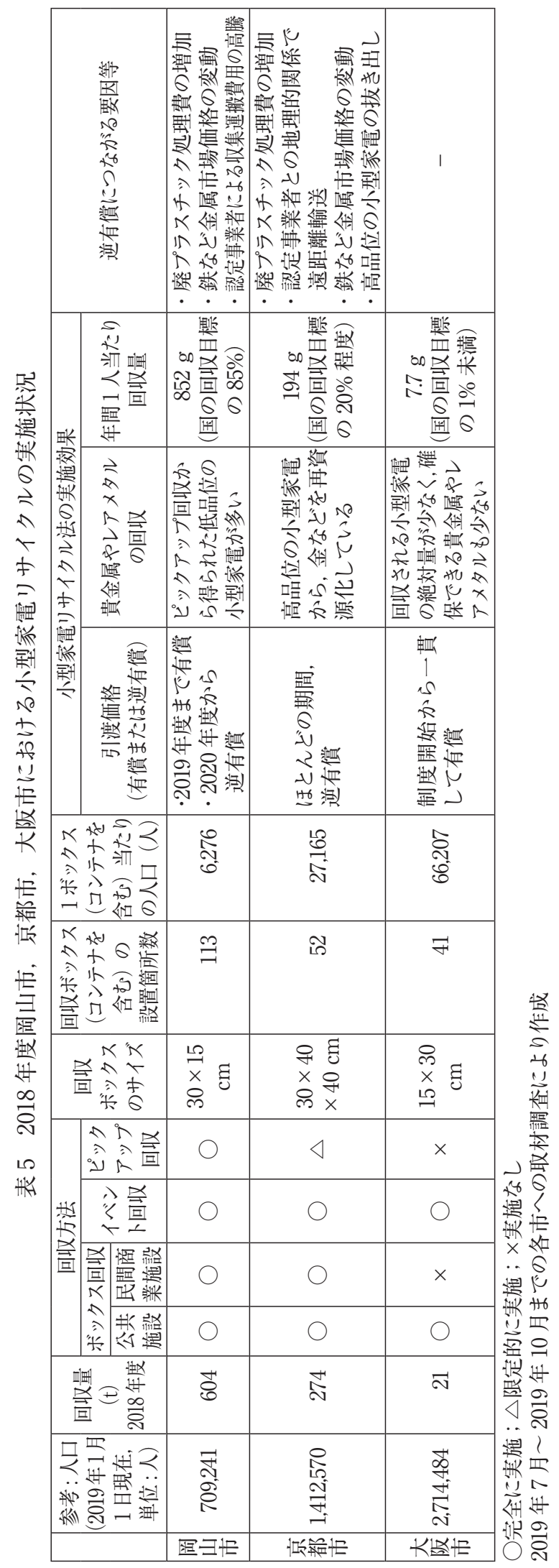


場合は, 2019 年度まで有償での引渡しを行ってき たが，(1)中国の輸入規制の影響で廃プラスチック などの処理費用が上昇し，また(2)金属市場の変動 により 2018 年度後半から鉄などの市場価格が下落 し続けた ${ }^{26)}$ ほか, (3) 100 ヶ所以上の協力電気店へ の巡回回収にかかる収集運搬費用の高騰などに よって, 現在契約している認定事業者が 2020 年度 以降逆有償での引取りを求めるにいたっている。 京都市の場合は, (1)廃プラスチックなどの処理費 用の上昇, (2)十分な処理能力を持つ認定事業者と の地理的関係, (3)鉄など金属の市場価格の変動な どが原因となり, 小型家電の逆有償での引渡しが 常態化している。

\section{4. 考察一市町村の実施現場で発生している課 題と解決の方向}

2.の問題分析と 3. の実態調査から, 回収量およ び希少金属の回収状況からみる小型家電の量的お よび質的回収状況, 認定事業者への引渡し価格に よる採算性等の側面から市町村の小型家電リサイ クルの状況を明らかにした。それに基づき, 上記の 量的および質的回収状況，および市町村の採算性 という視点から, 同制度の運営上, 市町村の実施現 場で発生している課題は以下の 4 点であると考え る。第 1 点目は小型家電の量と質に関する課題, 第 2 点目以降は市町村の採算性に関する課題である。

まず第 1 に, 小型家電回収量確保と高品位品確 保の両立の難しさがある。評価報告書は, 回収量 の拡大にステーション回収またはピックアップ回 収などの採用が有効であるとしているが，表 5 に 示したように, 粗大ごみ等からのピックアップ回収 を軸にした岡山市は, 2018 年度の年間 1 人当たり の回収量は国が立てた目標の $1 \mathrm{~kg}$ に近いが, 回収 できている高品位品は少ない。岡山市と同じく, 1 人当たり回収量の多い静岡市の場合, 2018 年度ま で回収品目を制限しない市民持ち込み回収を実施 し, 2018 年度の回収量は 599 トンに達していた。廃 プラ処理費の高騰などにより, 認定事業者への引 渡しは, 2018 年度の途中から一時逆有償になって いる。そのため, 2019 年度から回収対象品目を高 品位品を多く含む特定対象品目に絞り, 2019 年度 からは, 有償引渡しには復鹵しているものの, 回収 量は 208 トンと前年度から 3 分の 1 に減っている。
いずれにしても，評価報告書が揭げたステーショ ン回収やピックアップ回収を含め, 持ち込み回収な どの回収方法で回収量の拡大（規模の経済）をも たらしても，高品位品の回収量が少ない場合もあ り, 市町村に財政的な恩恵をもたらすとは限らない ことを示している。

第 2 に, 通常の一般廃棄物処理に比べた財政的 優位性確保の難しさがある。評価報告書には「見 えづらい便益」として, 逆有償になっても, 通常ご みの処理費より安ければ市町村にとってメリット があるとの指摘があった。しかし, 小型家電引渡し の逆有償額が通常の一般廃棄物処理単価より高く なっている事例が発生している。具体的には, 京都 市の 2018 年度第 4 半期の認定事業者への引渡し価 格は -60.8 円 $/ \mathrm{kg}$ であるのに対し, 同年度の然や

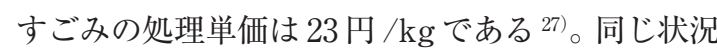
が名古屋市と北九州市にもみられた ${ }^{28)}$ 。現在, 引 渡し価格が一般廃棄物の処理単価を上回る市は政 令市の中でも少数であるが, プラスチック処理費用 や回収人件費の高騰, 金属市場の変動などにより, 逆有償引渡しの事例が拡大している中で, これか ら逆有償額が通常の一般廃裹物処理単価より高額 になるケースが増える可能性があると考えられる。

第 3 に，「見えづらい便益」だけではなく「見え づらい支出」があることである。前述の大阪市は 市職員が回収ボックスへの巡回, 認定事業者への 搬入を担っているが, このような回収, 運搬にか かった人件費や燃料費等が支出に明示されていな い。一方, 北九州市は, 認定事業者に回収ボック スへの回収作業を委託し，その回収費用を支出に 含めている。認定事業者による回収費用が小型家 電の売却費用を上回り, 結果として小型家電の引 渡しが逆有償になっている。評価報告書が「有償 での引渡しであっても, 輸送費を市町村が負担し, 実質的に逆有償による引渡しを行っている事例も ある（p10）」と述べるように，回収や運搬など小 型家電リサイクルのどの作業までを市町村の支出 に含まれているかが可視化されていないことから， 見えづらい支出を計上した場合，実質逆有償にな る市町村が多くなる可能性があると考えられる。

第 4 に，市町村と認定事業者の間に希少金属含 有量等の情報把握に非対称性が存在していること である。小型家電の回収は市場原理のもとで市町 


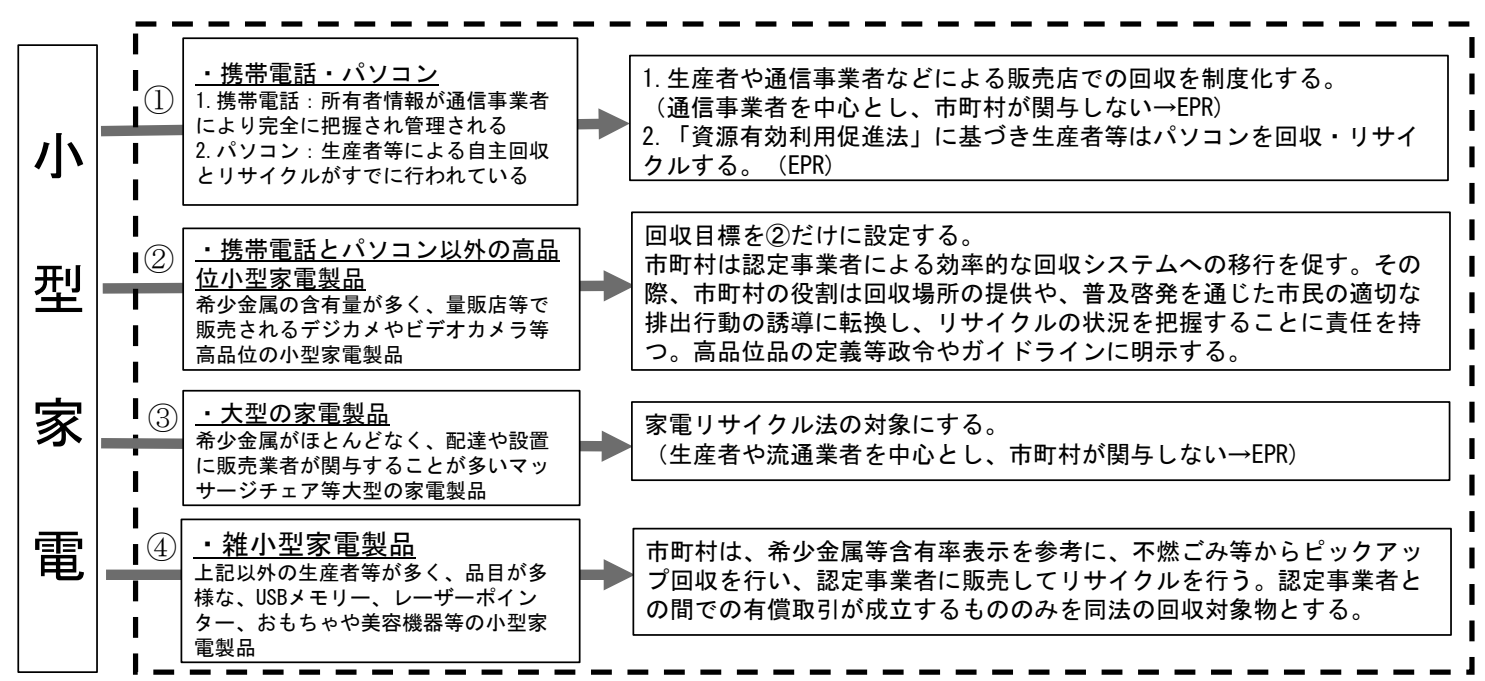

(5)すべての場合 : 希少金属と有害物質の含有率等を「生産者」が製品に表示する（EPR概念に含まれる内容）

図 1 制度改善の方向（筆者作成）

村の裁量に委ねているといいながら, 製品中にある 希少金属の種類および含有量，市場価値などの情 報は市町村に開示されていない。一方，認定事業 者は，回収・解体処理等の作業を通じて，希少金 属の含有量等の情報を蓄積することができる。この 情報の非対称性により，市町村は引渡し価格交涉 において十分な交渉力を持ちえず，認定事業者と 対等な立場では取引できないことになる。市町村の 採算性確保の困難はこの結果であるともいえる。

上記の市町村の実施現場で発生している課題の 背景にある要因として以下の 5 つのことが考えら れる。

第 1 に, 小型家電のうち希少金属を比較的多く 含む携带電話の回収については, 通信事業者, 生 産者および販売事業者が構築した「モバイル・リ サイクル・ネットワーク」が主に販売店店頭での回 収に自主的に取組んでいる ${ }^{29)}$ 。このような取組は, 特定の小型家電についての完全な回収を可能にす る性格を持つ。また，同じく希少金属が多く含ま れる高品位品としてのパソコンについては, 1991 年に制定された「再生資源の利用の促進に関する 法律」の一部を改正して 2001 年に施行された「資 源有効利用促進法」の中に，「指定再資源化製品」 としてすでに生産者等に自主的回収およびリサイ クルの責任を求めている。しかし，小型家電リサ イクル法のもとで回収をする市町村の立場から
は，そのような取り組み等の発展により回収作業 の負担は減るが, 高品位品回収の機会が減るため, 同法の目的の実現に困難をきたす可能性がある。

第 2 に, 小型家電の回収は市町村の裁量に任せ るといいながらも, 国は「重量」での回収量を目標 にしており，本来同法の主眼であった高品位品の 回収量が目標にされていないことである。

第 3 に,「小型家電」の対象とされる品目には, 希少金属がほとんどない大型の家電製品まで加え られてしまうことである。

第 4 に, 生産者等が多く, 種類が多様な雑小型 家電は, 小型家電の特徵を代表するものである。こ れらについては，収集や分別には人手がかかる傾 向があり，現行の小型家電リサイクル法の枠組み のもとにある回収システムでは, このような雑小型 家電に対する無差別的な回収は，収集・分別にか ける費用に対して希少金属回収益が少なくなり， 市町村の財政支出の増加につながる恐れがあると 考える。

第 5 に，すでに前記の課題 4 で述べた通り，市 町村の収益になる品目の絞り込みに有用な根拠と なる希少金属，さらに有害物質の含有率等が製品 に表示されていないことである。

そこで，以上の 5 つの要因と，小型家電製品に 関連する事業者の属性を考慮すると，小型家電り サイクル制度のこれからの改善の方向については 
図 1 に示すように, 現行の対象品目を 4 つのカテゴ リーに分け, 対応する施策を導入することが必要と 考えられる。

図 1 については, さらに以下の 5 点を補足した い。

第 1 に，「宝」である希少金属を多く含み，かつ 生産者の数も限られている高品位品としての携帯 電話等の端末の回収および再資源化を制度化する ことである。また, パソコンについては, 回収およ びリサイクルを「資源有効利用促進法」に基づい て行っていくことである。前述したように, 携带電 話等については, 生産者や通信事業者, 販売事業 者により構築された「モバイル・リサイクル・ネッ トワーク」のような個人情報のデー夕消去を含め てすでに取り組まれている回収の実態があり,パソ コンについても, 小型家電リサイクル法が施行され る前にすでに生産者等に自主的回収および再商品 化が同法と異なる法律によって求められている。 法施行前に,「携帯電話の回収協力条件として個人 情報に関わるデー夕の完全消去を求める人が多い ことから，携带電話を他の小型家電と一緒に回収 する方式は困難と考えられる」との指摘があり（中 野 2012), 法施行後も, 小型家電の排出実態に関す る研究により, 携帯電話やパソコンの排出につい て,「個人情報が流出しないか不安なため」をリサ イクル・処分しない理由として最も多く示されてい る（能登ら 2019）。したがって, 他の小型家電と異 なる性格を持つ携帯電話やパソコンの回収量を向 上させるためには，個人情報漏洩への懸念を拭う 必要がある。そのためには所有者情報が完全かつ 高度に把握され管理される事業者等による回収が 排出者の利便性や安心感も含めてより効率的であ ると考えられる。容器包装リサイクル法において 「容器包装の利用業者」にも再商品化義務を課して いるように, 携带電話の場合, 機器の生産者では なく, 機器の実働状態を掌握している通信事業者 等が回収主役になることが考えられる。上記ネット ワークは「宝」の回収に自主的に取り組むことで, EPR 的方式が実現できるシステムだといえる。そ のため, 小型家電リサイクル制度の中で, 通信事 業者等による高度に管理された携帯電話といった 情報機器については通信事業者等による上記の回 収システムを制度化していくことが効果的である。
一方, パソコンの回収とリサイクルは小型家電リサ イクル法から完全に分離し，現行の「資源有効利 用促進法」の管轄に完全に移転する方が有効的で はないだろうか。

第 2 に, 携帯電話やパソコン以外の希少金属が 多く含まれ, 量販店等で販売されるデジタルカメラ やビデオカメラ等高品位の小型家電については, 生産者による情報開示を通じて, 引取り交渉にお ける認定事業者に対する市町村の立場を強くする ことで，現行制度の微修正を行うことが考えられ る。しかし，市町村を介さず，認定事業者が自主 回収から再資源化までの一連の作業を行えば，経 済的にも無駄を除くことができる一方, 市町村の負 担も大きく軽減され，「促進型」の主旨に沿うもの となり得る。その際, 市町村は回収場所の提供や, 普及啓発を通じて市民の適切な排出行動を誘導す る一方, リサイクルの状況把握に責任を持つ。

このような回収方法においては，回収目標を小 型家電製品全体に対して設定するより，高品位品 だけに回収目標を設定するよう転換する必要性が ある。資源確保を主目的の一つに掲げた小型家電 リサイクル法の趣旨を生かす場合, 従来の市町村 の金属回収の枠組みを越えて，希少金属を多く含 む高品位小型家電の回収システムを構築する必要 があることから, 今後は高品位品の回収をさらに重 視すべきであろう。一方, 高品位品の定義や判断 の仕方等については, 政令やガイドラインに明示す る必要があると考えられる。

第 3 に，希少金属をほとんど含んでいないマッ サージチェアのような大型の家電製品の配達や設 置は販売事業者によって行われており，現行の家 電リサイクル法の対象品目に追加し,引き取りまた は処理・リサイクルの責任を家電メーカーや流通事 業者等に負わせる形で EPR を導入することができ るはずである。これにより, 現行の小型家電リサイ クル制度のもとで発生している市町村の採算性確 保の困難さを緩和する効果が期待できると考えら れる。

第 4 に，上記以外の品目および生産者が多様な 雑小型家電製品については，生産者による金属含 有率表示の義務化という弱い EPR の導入で, 認定 事業者との間での公正な取引が成立するもののみ を小型家電リサイクル法の対象物とし，市町村は 
不燃ごみ等からピックアップ回収を行い, 認定事 業者に販売してリサイクルを行うことが考えられ る。雑小型家電の多様性から, これ以上の生産者 の組織化等によるより強い EPR の導入は容易では ないと考えられる。この場合, 市場原理のもとでリ サイクルが可能なもののみを同法の対象とするこ とで, 市町村に無駄な負担をさせることなく, 同法 の趣旨を生かすことができると考えられる。

第 5 に, 使用済小型家電のリサイクルが適正に 実施されるようにするためには，すべての小型家 電製品に含有する希少金属と有害物質の含有率等 を「生産者」が製品に表示することは基本的課題 である。循環基本法の第 11 条により規定された EPR の内容, すなわち「廃棄物となることを抑制 するために必要な措置, 製品または容器の回収お よびリサイクルに関する措置, 当該製品, 容器等 の設計の工夫および材質または成分の表示など」 （下線部は引用）に基づいて, 技術情報が漏れない 範囲で製品に含まれる希少金属の含有率を製品に 表示するといった責任を生産者に課すことであ る。一方，開示すべき情報は，希少金属に関する ものだけではなく，処理時に発生する恐れのある 有害物質成分に関する情報の開示も必要であろ う。

\section{5. まとめ}

本研究は, 小型家電の回収量確保, 特に希少金 属の循環利用により回収主体となる市町村にとっ て採算性のある制度になるとの期待のもと, 生産 者などに義務を課さずに「促進型の制度」として 運用されてきた小型家電リサイクル法の実施状況 と市町村の実施現場における課題について考察し た。具体的には, 政令市 20 市における小型家電り サイクルの取組を概観した上で, 年間 1 人当たり回 収量を基準にグループ化し，その中から特徴的と 考えられる岡山市, 京都市, 大阪市を選び, より詳 細な実態調查を行った。今回の調査で, 岡山市, 京 都市, 大阪市の 3 市それぞれの認定事業者への引 渡し価格, 希少金属の回収状況, 年間 1 人当たり 回収量に大きな違いが生まれている。また, 3 市へ の実態調査および同制度への問題分析から, (1)小 型家電の回収量確保と高品位品の回収量確保の両 立の難しさ, (2)逆有償額が一般廃棄物処理費を上
回る可能性があること, (3)市町村による回収や運 搬にかかった人件費, 燃料費等のような見えづら い支出があること, (4)市町村と認定事業者の間に 希少金属含有量等の情報把握に非対称性が存在し ていること, という 4 つの課題を確認した。

市町村の実施現場で発生している上記 4 つの課 題の背景にある諸要因と小型家電に関連する事業 者の属性を考慮し, 小型家電リサイクル制度のこ れからの改善の方向として, 以下の 5 点を提示し た：

1.「宝」である希少金属を多く含み, かつ生産者 の数も限られている高品位品としての携带電話 等の端末の回収および再資源化については, こ れまでの事業者による取組を制度化し，また, パ ソコンについては,「資源有効利用促進法」に基 づいて回収・リサイクルを行う。

2. 携帯電話やパソコン以外の, 希少金属を多く含 み, 量販店等で販売されるビデオカメラやデジ タルカメラ等の高品位小型家電については, 市 町村は認定事業者による効率的な回収システム への移行を促す。その際, 市町村の役割は回収 場所の提供や，普及啓発を通じた市民の適切な 排出行動の誘導に転換し, リサイクルの状況把 握に責任を持つ。

3. 希少金属がほとんどなく, 配達や設置に販売事 業者が関与しやすいマッサージチェア等のよう な大型の家電製品については, 現行の家電リサ イクル法の対象品目に追加し,引き取りまたは処 理・リサイクルの責任を家電メーカーや流通事 業者等に負わせる形で EPR を導入する。

4. 上記以外の品目および生産者が多様な雑小型家 電製品については，生産者による金属含有率表 示の義務化という弱い EPR の導入で, 認定事業 者との間での公正な取引が成立するもののみを 小型家電リサイクル法の対象物とし, 市町村は 不燃ごみ等からピックアップ回収を行い, 認定 事業者に販売してリサイクルを行うことが考え られる。

5. 以上全ての項目に対応するリサイクルを効果的 に行うためには, 技術情報が漏れない範囲で, 循 環基本法の第 11 条により規定された EPRの一 項目,「製品等の設計の工夫および材質または成 分の表示」内容に基づき，製品に含まれる希少 
金属含有率表示を有害物質含有率表示を含めて 生産者に義務付ける。

\section{謝辞}

本調査にご協力いただいた各市のご担当者に感 謝申し上げます。また, 堀尾正靶先生（東京農工 大学名誉教授, 元龍谷大学政策学部特任教授）か らは貴重なご指導をいただきました。

\section{注}

1 )「使用済小型電子機器等の再資源化の促進に関する 基本方針（2013 年)」（以下，基本方針）に，同法が 促進型を採った背景が述べられている。

2 )「基本方針（2013 年)」に規定された使用済小型電 子機器等の再資源化の促進の基本的方向に明記して いる。

3 ）産業構造審議会·中央環境審議会合同会合（2020） 「小型家電リサイクル制度の実施状況の評価・検討に 関する報告書」p6 参照

https://www.meti.go.jp/shingikai/sankoshin/ sangyo_gijutsu/haikibutsu_recycle/kogata_wg/ pdf/20200807_01.pdf 2020年 8 月 21 日閲覧.

4 )「基本方針（2013 年）」は 2015 年度の回収目標を 14 万トンに設定した。この 14 万トンは, 2011 年の 使用济小型家電の推計排出量の約 2 割に相当して設 定された。しかし，2015 年度の回収実績は 6.7 万卜 ンに過ぎなかったため，2017 年度に基本方針が改正 され，2018 年度まで目標は 14 万トンで据え置かれ た。

5 ）前掲 3.p4 参照

6 ）前掲 3.p10 参照

7 ）小型家電リサイクル法の第 10 条により, 使用済小 型家電等の再資源化のための使用済小型家電等の収 集，運搬㧍よび処分の事業を行おうとする者は，再 資源化事業の実施に関する計画を作成し，主務大臣 からの認定を受けることで認定事業者となる。

8 ）前掲 3. 第 3 章「具体的な方策」p16に, 有害金属 対策費用の削減を見えづらい便益とし，最終処分場 の延命効果を財政的に評価しづらいメリットとして 指摘されている。

9 ）同法の制定背景について，まず環境省・経済産業 省（2008）「第 1 回使用済小型家電からのレアメタル の回収及び適正処理に関する研究会レアメタルリ サイクルの現状」資料 3 は, 小型家電製品の中には, 重量あたりの貴金属やレアメタルの含有率が高い製 品があると指摘し，前掲 1 .の基本方針および中央環 境審議会·産業構造審議会合同会合（2014）「小型家
電リサイクル法の概要について」資料 1-1 p1 は，小 型家電リサイクル法の制定以前, 使用済小型家電等 は一般廃棄物として市町村が回収処理を行い，回収 処理の段階では，鉄やアルミなど一部の金属だけが 回収され，金などの貴金属やレアメタル等の大部分 は埋立て処分されていたと報告している。そのため, 貴金属やレアメタルのリサイクルを促進して資源の 有効な利用の確保を図るというのが法律の立法趣旨 の一つであると考えられる。本研究では, 有用金属 のうち貴金属やレアメタルに注目し，その再資源化 を検証指標とする。

10）改正された「基本方針（2017 年)」により,2018 年 度までの年間 1 人当たり回収量は $1 \mathrm{~kg}$ と設定されて いる。

11）内閣府「使用済小型電子機器等の再資源化の促進 に関する法律施行令」第 45 号第 1 条参照 http://www.env.go.jp/recycle/recycling/raremetals/ law/go_h25-45.pdf 2020 年 1 月 3 日閲覧.

12）経済産業省・環境省（2013）「使用済小型電子機器 等の回収に係るガイドライン」 pp.8-9 参照 http://www.env.go.jp/recycle/recycling/raremetals/ attach/gl_collect130306.pdf 2020 年 1 月 3 日閲覧.

13）中央環境審議会 (2012)「小型電気電子機器リサイ クル制度の在り方について (第一次答申) 」 $\mathrm{p} 27$ 参照 https://www.env.go.jp/press/files/jp/19123.pdf 2019 年 10 月 8 日閲覧.

14）小型家電リサイクル法の第 1 条（目的）では，同 法の目的を「廃棄物の適正な処理及び資源の有効な 利用の確保」と明示しているが, ここでの廃棄物の 適正な処理には，廃棄物の減量化と有害物質管理と いう $2 つ の$ 側面が含まれると考える。これについて, 前掲 1. 基本方針の $\mathrm{p} 1$ から $\mathrm{p} 2$ でも言及している。た だし，有害物質管理に関する議論は本研究で展開し ない。

15）前掲 13.p22 参照

16）前掲 3.p9 参照

17）総務省行政評価局（2017）「小型家電リサイクルの 実施状況に関する実態調查結果報告書」 $\mathrm{p} 22$ 参照 http://www.soumu.go.jp/main_content/000520790. pdf 2019 年 3 月 2 日閲覧.

18） 2019 年 10 月 24 日の岡山市環境事業課へのインタ ビューによる。

19）岡山市へのインタビュー調查により，回収した小 型家電は低品位のものが多いことがわかった。また， 大栄環境株式会社の広報資料 (2015)「小型家電り开 イクルビジネスの現状と今後」 $\mathrm{p} 14$ および $\mathrm{p} 20$ には, ピックアップ回収でのパソコン, 携帯電話などの高 品位品の回収率はわずかで, 中品位品と低品位品が 多くの割合を占めていることが報告されている。 
http://www.fsrj.org/act/8_event/H27-3-11/4,\%20 Nishino.pdf 2020 年 5 月 20 日閲覧.

20）岡山市環境事業課へのインタビューおよび前掲 19. 大栄環境（株）広報資料 $\mathrm{p} 19$ による。

21） 2019 年 11 月 19 日の京都市循環型社会推進部ごみ 減量推進課への取材による。

22）前掲 3.p9 金の相場を参照。

23) 京都市 2018 年度の小型家電の引渡し単価の 4 期平 均と 2018 年度の回収量を乗じて筆者計算。

24）2019年 10 月 9 日の大阪市環境局事業部家庭ごみ 減量課へのインタビューによる。

25） 2020 年 5 月 25 日の大阪市環境局事業部家庭ごみ 減量課への電話取材による。

26）産業新聞 鉄スクラップ価格の推移による。https:// www.japanmetal.com/memberwel/marketprice/ soba_h2, 2020 年 5 月 20 日閲覧.

27） 2020 年 9 月 9 日の京都市循環型社会推進部ごみ減 量推進課への電話取材による。

28）2018 年度名古屋市における小型家電の引渡し価格 は逆有償で -42 円 $/ \mathrm{kg}$ である（2020 年 9 月 9 日名古 屋市環境局への電話取材により）のに対して, 資源 ごみを除く同年度のごみ処理単価は 34 円 $/ \mathrm{kg}$ (焼却・ 破砕 32 円，埋立 2 円）である。

名古屋市環境局（2020）「名古屋ごみレポート’ 19 版」p17 参照 http://www.city.nagoya.jp/kankyo/ cmsfiles/contents/0000015/15557/zentai.pdf 2020 年 9 月 11 日閲覧.

北九州市の 2018 年度の認定事業者への引渡し価格 は逆有償で -37.3 円 $/ \mathrm{kg}$ である（2020 年 9 月 9 日北 九州市環境局環境経済部環境産業推進課への電話取 材により）のに対して, 家庭ごみの処理単価は 34.4 円 $/ \mathrm{kg}$ である。家庭ごみ処理単価は, 「北九州市の環 境」令和元年度版を参照し, 2017 年度家庭ごみ収集 量 18 万トンと処理費 62 億円から筆者が計算した。 2020 年 9 月 9 日取材時に 2018 年度家庭ごみ処理費 用は未公開である。

29）「モバイル・リサイクル・ネットワーク」HP https:// www.mobile-recycle.net 2020 年 9 月 20 日閲覧.

\section{参考文献}

相澤寛史・平井康宏・酒井伸一（2009）「日本にお ける小型電気電子機器のリサイクル」『廃棄物資 源循環学会論文誌』Vol.20, No.6, pp.371-382.

天池恭子 (2012)「使用済小型電子機器等のリサイ クル制度の構築 - 小型家電リサイクル法の成立」 『立法と調查』No.334, pp.51-59.

藤田実花（2013）「小型家電リサイクル法の経緯と
課題」『調査と情報』第 780 号, pp.1-10. 樋口隆哉（2014）「宇部市における小型家電のボッ クス回収状況およびリサイクルに対する住民意 識の調査」第 25 回廃裹物資源循環学会研究発表 会講演原稿 B1-7, pp.137-138.

細田衛士（2011）「使用済み小型家電リサイクルの 展望と課題」『INDUST』Vol.26, No.10, pp.5-9. 飯野成憲・辰市祐久・茂木敏・吉田慎太郎・寺園 淳・小口正弘・荒井康裕 (2014) 「小型家電リサ イクル法に基づくボックス回収等の実態」第 25 回廃棄物資源循環学会研究発表会講演原稿 B14, pp.131-132.

飯野成憲・辰市祐久・茂木敏（2017）「小型家電製 品の回収品目と回収方法に関する考察」『都市清 掃』第 70 巻, 第 336 号, pp.29-36.

礒野弥生（2013）「小型家電リサイクル法と拡大生 産者責任」『都市問題』2013.1, pp.78-86.

小林寛 (2014)「小型家電リサイクル法の今後の課

題に関する考察ーリサイクル関連法との比較に 基づいて-」『長崎大学総合環境研究』17 (1), pp.1-10.

中村崇 (2017)「廃小型電気・電子機器のリサイク ル促進に向けて」『都市清掃』第 70 巻, 第 336 号, pp.18-23.

中野加都子 (2012)「消費者の視点から見た小型家

電の効率的なリサイクルに向けて:ひょうごエコ タウン推進会議によるアンケート調査結果より」

『月刊廃棄物』2012.2, pp.18-22.

中野加都子 (2017)「小型家電リサイクル定着への 取り組み: 都市鉱山からつくる金銀銅メダル」 『環境施設』2017.12, pp.46-50.

能登大貴・和田有朗 (2019)「使用済み小型家電の 排出実態の把握と小型家電リサイクル促進への 取り組みの提案」『土木学会論文集 $G$ (環境)』 Vol.75, No.5, pp.193-200.

岡本拓郎・望月啓介・前田茂行・鈴木慎也（2017）

「福岡市における家庭系不燃ごみ中の小型電子 機器等排出状況」第 28 回廃裹物資源循環学会研 究発表会講演原稿 A3-7P, pp.33-34.

岡本拓郎・荒巻裕二・前田茂行・鈴木慎也 (2018)

「福岡市における使用済小型電子機器回収ボッ クスの設置場所別回収量」第 29 回廃棄物資源循 環学会研究発表会講演原稿 A5-1, pp.57-58. 
岡山朋子・神本祐樹・市野良一 (2014)「小型家電 リサイクル法の実施実効性に関するケースス夕 ディ」第 25 回廃棄物資源循環学会研究発表会講 演原稿 A5-1, pp.51-52.

大塚直（2012）「小型家電リサイクル法の意義と法 的課題」『廃棄物資源循環学会誌』Vol.23, No.4, pp.319-326.

齋藤優子・劉庭秀（2016）「日本における小型家電 リサイクル政策の現状と課題 - 自治体および認 定事業者の実態調查分析を中心に一」『MACRO REVIEW』Vol.28, No.1, pp.1-12.

櫻井義夫（2013）「小型家電リサイクル制度の概要 とポイント」『INDUST』Vol.28, No.4, pp.18-23. 佐藤泉（2017）「小型家電リサイクルの法的課題」 『都市清掃』第 70 巻, 第 336 号, pp.24-28. 杉村佳寿 (2012)「小型家電リサイクル法について」 『生活と環境』Vol.57, No.11, pp.4-11.

植田和弘（1992）『廃棄物とリサイクルの経済学』 有斐閣. pp.24-28.

山末英嗣・沼田健・奥村英之・石原慶一（2009） 「使用済み携帯電話およびパーソナルコン ピュータに含まれるレアメタル量の推計とその インパクト評価」『日本金属学会誌』第 73 巻, 第 3 号, pp.198-204.

吉田文和（2013）「都市鉱山の経済性を考える」『都 市問題』2013.1, pp.69-77.

経済産業省リサイクル推進課（2017）「小型家電リ サイクル制度の意義と今後への期待」『都市清 掃』第 70 巻, 第 336 号, pp.14-17.
OECD (2001) Extended Producer Responsibility: A GUIDANCE MANUAL FOR GOVERNMENTS, OECD.

総務省（2019）「市区町村別人口，人口動態及び世 帯数」を参照

https://www.e-stat.go.jp/stat-search/files?page $=1$ \&layout $=$ datalist\&touke $=00200241 \&$ bunya_ $1=0$ $2 \&$ tstat $=000001039591 \&$ cycle $=7 \&$ year $=20190 \&$ month $=0 \&$ tclass $1=000001039601 \&$ result back $=12019$ 年 10 月 8 日閲覧.

環境省・経済産業省（2008）「第 1 回 使用済小型 家電からのレアメタルの回収及び適正処理に関 する研究会 レアメタルリサイクルの現状」資 料 3, pp.5-8 参照

http://www.env.go.jp/recycle/recycling/raremetals/ conf_ruca/01/mat03.pdf 2020 年 5 月 16 日閲覧. 中央環境審議会・産業構造審議会合同会合（2014） 「小型家電リサイクル法の概要について」資料 1-1, p1参照 http://www.env.go.jp/council/ 03recycle/y038-13/mat01_1.pdf 2020 年 5 月 17 日 閲覧.

中央環境審議会・産業構造審議会合同会合（2020）

「小型家電リサイクル制度の施行状況について」 資料 3, p11, p18 参照 http://www.env.go.jp/council/ 03recycle/3\%20sekoujyoukyou.pdf 2020 年 5 月 17 日閲覧.

$(2020$ 年 10 月 19 日受付, 2021 年 5 月 28 日受理) 